\title{
Anthracene coupled adenine for the selective sensing of copper ions
}

\author{
Kumaresh Ghosh ${ }^{*}$ and Tanushree Sen
}

\section{Full Research Paper}

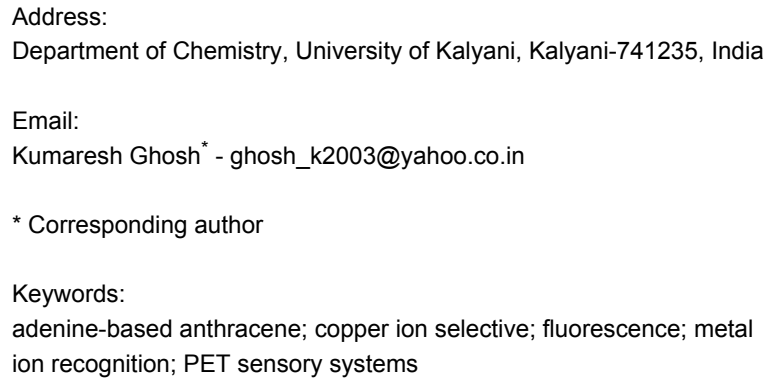

Beilstein J. Org. Chem. 2010, 6, No. 44. doi:10.3762/bjoc. 6.44

Received: 21 January 2010

Accepted: 09 April 2010

Published: 05 May 2010

Editor-in-Chief: J. Clayden

(c) 2010 Ghosh and Sen; licensee Beilstein-Institut. License and terms: see end of document.

\begin{abstract}
Anthracene-based adenines $\mathbf{1}$ and $\mathbf{2}$ have been designed and synthesized, and their metal ion recognition properties have been established fluorometrically. Both molecules exhibit $\mathrm{Cu}^{2+}$ induced ON-OFF type signaling patterns over the other representative metal ions studied. Compound 1 exhibits $97 \%$ quenching of emission in the presence of $\mathrm{Cu}^{2+}$ whilst derivative 2 shows $81 \%$ quenching under similar experimental conditions.
\end{abstract}

\section{Introduction}

Fluorescent chemosensors for the detection of biologically relevant metal ions have been widely exploited in the field of supramolecular chemistry [1-4]. Among the various transition metal ions, the copper ion draws significant attention due to its crucial role in biological systems. This metal ion causes significant environmental pollution and also serves as a catalytic cofactor for a variety of metalloenzymes [5-9]. However, exposure to high levels of copper, even for a short period of time, can cause gastrointestinal disturbance, while long-term exposure can lead to liver or kidney damage [10-16]. For these reasons, the past few years have witnessed a number of reports on the design and synthesis of fluorescent sensors for the detection of $\mathrm{Cu}^{2+}$ ions [17-24]. Although there are various reports in this regard, synthetic receptors with improved binding efficiency are still in demand. In addition, the coordination of the metal ion with nucleobases plays an important role in the stability of the nucleic acid structure [25]. Among the nucleobases adenine provides five interactional sites for coordination with metal atoms. Although it has already been established that adenine moiety exhibits preferential coordination of silver ions [26], the formation of $\mathrm{Cu}$ (II) complexes of substituted adenines is also known in the literature [27]. Depending on the smaller size of the substituent at $\mathrm{N} 9$ position of adenine, a preferential coordination of $\mathrm{Cu}^{2+}$ ion at N7 over N1 or N3 is found to occur for bisadenine ligands [27]. Smaller substituents lead to simultaneous binding of silver ion at all the three centers. However, in this paper we wish to report that introduction of an anthracenyl group (a flat hydrophobic surface) at the different positions in adenine leads to the preferential binding of $\mathrm{Cu}^{2+}$ ion over $\mathrm{Ag}^{+}$and other transition metal ions studied. In this connec- 
tion, adenine-based receptors 1 and $\mathbf{2}$ (Scheme 1) have been synthesized and their metal ion binding properties have been studied by UV-vis and fluorescence methods. Both $\mathbf{1}$ and $\mathbf{2}$ are found to be selective for $\mathrm{Cu}^{2+}$ in $\mathrm{CH}_{3} \mathrm{CN}$ containing $0.02 \%$ DMSO. Importantly, $\mathbf{1}$ is found to be more efficient binder than $\mathbf{2}$ as reflected in the study.
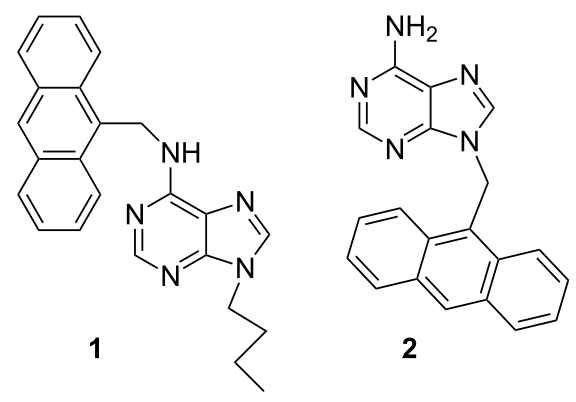

Scheme 1: Adenine-based receptors 1 and 2.

\section{Results and Discussion}

The syntheses of $\mathbf{1}$ and $\mathbf{2}$ are outlined in Scheme 2. First, 9-position of adenine was alkylated in the presence of $\mathrm{NaH}$ in dry DMF using 9-chloromethylanthracene, obtained from the reaction of 9-anthracenyl alcohol with thionyl chloride, to afford 2 [28] in 50\% yield. In a similar manner, 9-butyladenine 3 was obtained from the reaction of adenine with $n$-butyl bromide in the presence of $\mathrm{K}_{2} \mathrm{CO}_{3}$ in dry DMF. Further reaction of 3 with 9-chloromethylanthracene led to the compound 1 [29] in $60 \%$ yield. All the compounds were characterized by conventional methods [30].

The adenine-based molecules $\mathbf{1}$ and $\mathbf{2}$ were designed according to the design principle of a PET sensor, shown in Figure 1. In both $\mathbf{1}$ and $\mathbf{2}$, adenine is defined as the binding site, which is connected to the anthracene probe via $-\mathrm{CH}_{2}-$ spacer at the different regions of adenine.

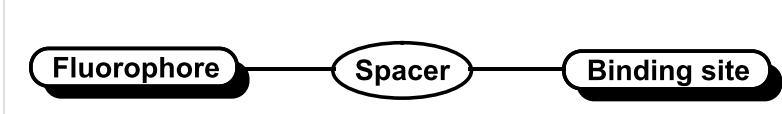

Figure 1: Design principle for 1 and 2.

In order to find out the possible site for binding of metal ions, we optimized the geometries of both $\mathbf{1}$ and $\mathbf{2}$ at AM1 level in the gas phase [31]. In 1 the disposition of anthracene at the Watson-Crick (WC) site is favored over its orientation at the Hoogsteen (HG) site. This is in accord with the previous report by Engel et al. [32]. We also noted this phenomenon in our previous report [30]. The charge densities at the different nitrogen centers are shown in Figure 2. It is evident from Figure 2, that the WC sites in $\mathbf{1}$ and $\mathbf{2}$ provide relatively greater charge density than the HG sites. Thus it is presumed that the binding of metal ion will preferably take place in solution at the WC site in both cases, although the binding at the HG site cannot be ruled out. This is in accord with the observation of Glass et al. [33]. It is worth noting that the introduction of the alkyl group on the amino group of adenine modulates the charge densities at the WC site. On going from structure 1 to structure $\mathbf{2}$, the charge densities at the WC sites are marginally increased (Figure 2).

Fluorescence and UV-vis spectroscopic techniques were then employed to ascertain the metal ion recognition properties of both $\mathbf{1}$ and $\mathbf{2}$ in solution.

Receptor $1\left(c=5.09 \times 10^{-5} \mathrm{M}\right)$ upon excitation at $348 \mathrm{~nm}$ in $\mathrm{CH}_{3} \mathrm{CN}$ containing $0.02 \%$ DMSO showed structured emission centered on $413 \mathrm{~nm}$. Upon the gradual addition of metal ions as their perchlorate salts to the receptor solution of $\mathbf{1}$, the emission of $\mathbf{1}$ decreased by different extents. Figure 3 a demonstrates the change in emission of $\mathbf{1}$ upon the addition of 20 equivalents of metal ion and clearly shows that the emission of $\mathbf{1}$ is quenched to the greatest extent by the $\mathrm{Cu}^{2+}$ ion. Figure $3 \mathrm{~b}$ is the Stern-Volmer plot, which gives a comparative view on the

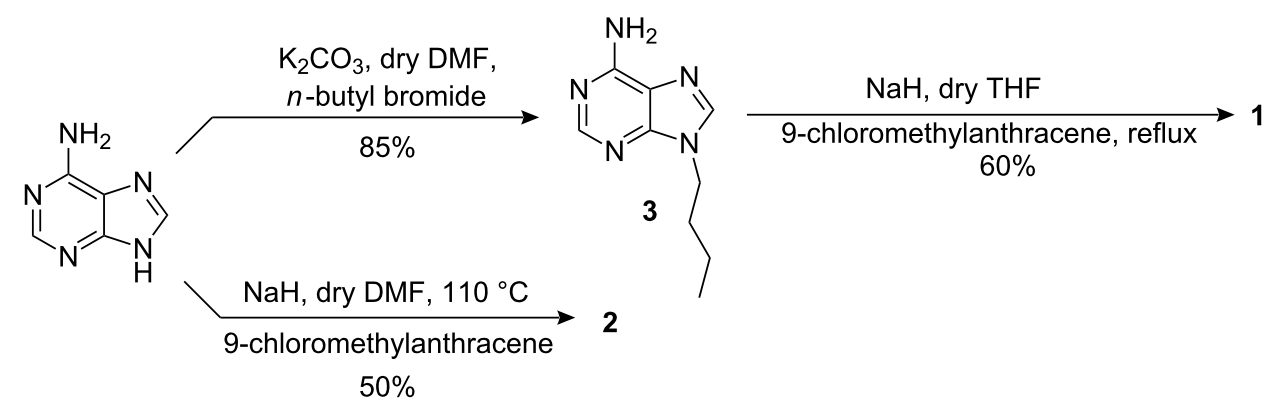

Scheme 2: Syntheses of receptors 1 and 2. 

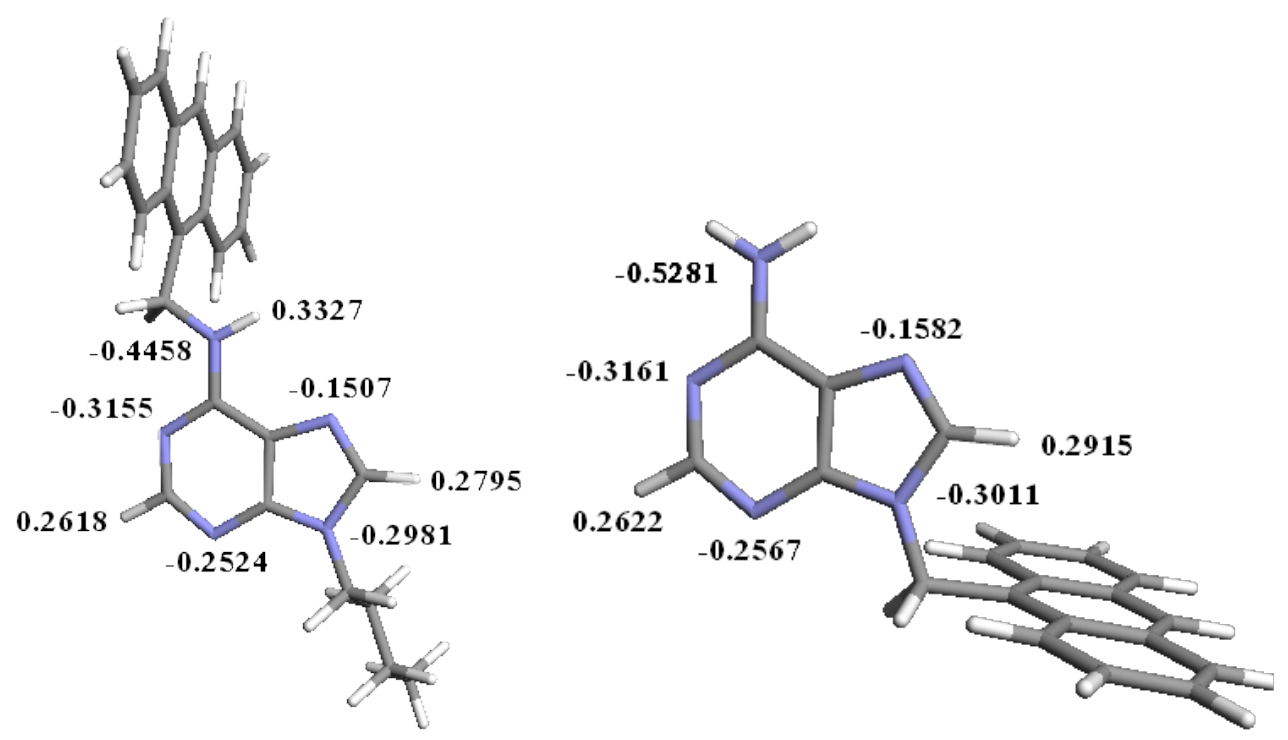

Figure 2: AM1 optimized geometries of $1(E=-162.48 \mathrm{au})$ of $2(E=-139.59 \mathrm{au})$.

quenching of emission of $\mathbf{1}$. The almost linear nature of the curves for $\mathbf{1}$ in Figure $3 \mathrm{~b}$ corroborates the quenching dynamic in nature and shows a clear distinction between $\mathrm{Cu}^{2+}$ ion and the other metal ions investigated. During interaction of 1 with metal ions no additional peak at higher wavelengths either for excimer or exciplex formation should be observed. Figure 4 shows the spectral change of 1 upon titration with $\mathrm{Cu}^{2+}$ metal ions.

A similar trend in emission behavior was observed with receptor 2 . Receptor $2\left(c=1.48 \times 10^{-5} \mathrm{M}\right)$ gave an emission spectra of triplet nature with the highest peak at $413 \mathrm{~nm}$ on excitation at $348 \mathrm{~nm}$. The emission intensity of 2 was quenched on titration with metal ion solutions as used with compound $\mathbf{1}$. Like 1, the maximum quenching occurred on the successive addition of the $\mathrm{Cu}^{2+}$ salt to a solution of receptor 2 . Figure $5 \mathrm{a}$ shows the changes in emission intensity of receptor $\mathbf{2}$ during complexation with $\mathrm{Cu}^{2+}$ ions. Titration experiments were also performed with the other metal salts, which also caused quenching, but not to the same extent as with $\mathrm{Cu}^{2+}$ ion. Figure $5 \mathrm{~b}$ shows a comparative view in the change in emission of 2 during titration with different metal ion solutions and Stern-Volmer plot in Figure 6 represents the linear nature of the curves indicating dynamic quenching during the interaction process.
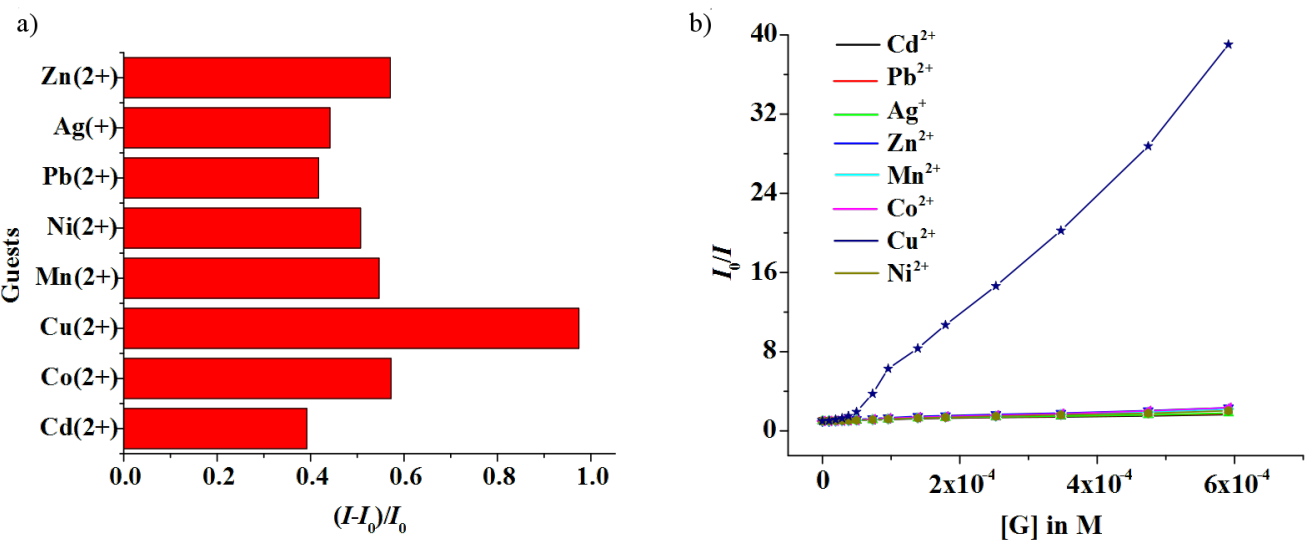

Figure 3: a) Fluorescence ratio $\left(I-I_{0} / I_{0}\right)$ of receptor $1\left(c=5.09 \times 10^{-5} \mathrm{M}\right)$ at $413 \mathrm{~nm}$ upon addition of 20 equiv of a particular guest in $\mathrm{CH}_{3} \mathrm{CN}$ containing $0.02 \%$ DMSO $\left(\lambda_{\mathrm{ex}}=348 \mathrm{~nm}\right)$; b) Stern-Volmer plot of receptor $1\left(c=5.09 \times 10^{-5} \mathrm{M}\right)$ at $413 \mathrm{~nm}$ upon addition of 20 equiv of a particular guest in $\mathrm{CH}_{3} \mathrm{CN}$ containing $0.02 \%$ DMSO $\left(\lambda_{\mathrm{ex}}=348 \mathrm{~nm}\right)$. 


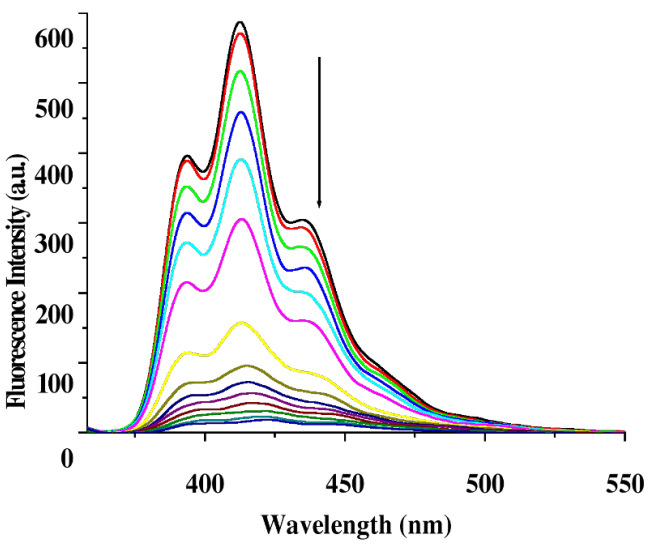

Figure 4: Emission spectra of receptor $1\left(c=5.09 \times 10^{-5} \mathrm{M}\right)$ during titration with $\mathrm{Cu}^{2+}$ ion $\left(c=1.4 \times 10^{-3} \mathrm{M}\right)$ in $\mathrm{CH}_{3} \mathrm{CN}$ containing $0.02 \%$ $\operatorname{DMSO}\left(\lambda_{\mathrm{ex}}=348 \mathrm{~nm}\right)$.

From both Figure 5b and Figure 6 it is evident that receptor 2 also shows a similar fluorometric response as observed for $\mathbf{1}$ and selectivity for $\mathrm{Cu}^{2+}$ ions. The only difference between $\mathbf{1}$ and $\mathbf{2}$ is the extent of quenching of emission. The greater degree of quenching of emission in both $\mathbf{1}$ and $\mathbf{2}$ in presence of $\mathrm{Cu}^{2+}$ ions may presumably occur by the chelation enhanced anthracene $\rightarrow \mathrm{Cu}^{2+} \pi$-cation interactions, the paramagnetic effect of $\mathrm{Cu}^{2+}[34-36]$.

To understand the selective sensing of $\mathrm{Cu}^{2+}$ by both $\mathbf{1}$ and $\mathbf{2}$, we recorded the emission spectra of the receptors with the addition of 10 equivalents of $\mathrm{Cu}^{2+}$ to the receptor solutions containing 10 equivalents of a mixture of other metal ions examined in the present study. Figure 7 displays the comparative view of the change in emission of $\mathbf{1}$ and $\mathbf{2}$ in the presence of $\mathrm{Cu}^{2+}$ when the

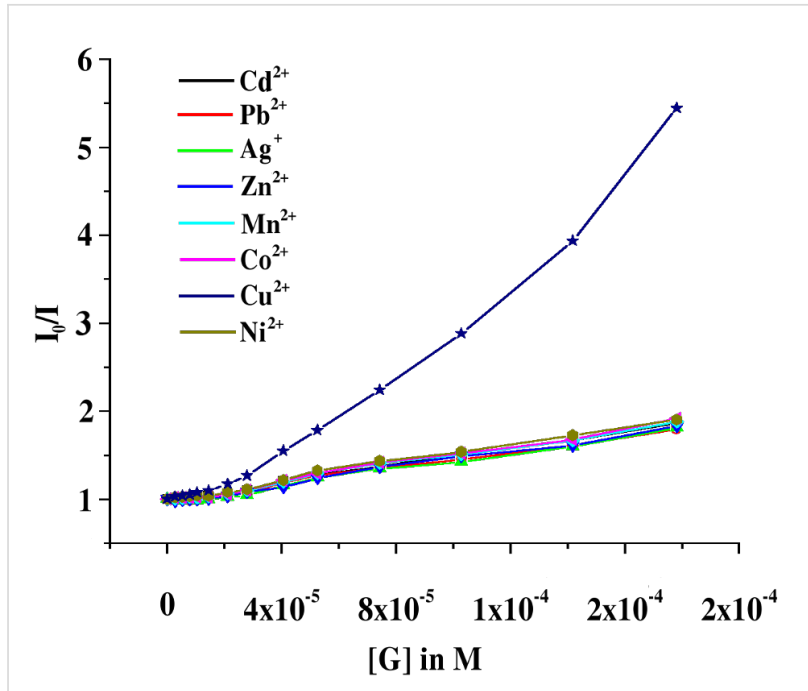

Figure 6: Stern-Volmer plot of receptor $2\left(c=1.48 \times 10^{-5} \mathrm{M}\right)$ at 413 $\mathrm{nm}$ upon addition of 20 equiv of a particular guest in $\mathrm{CH}_{3} \mathrm{CN}$ containing $0.02 \%$ DMSO $\left(\lambda_{\mathrm{ex}}=348 \mathrm{~nm}\right)$.

other metal ions are absent and present in the receptor solutions. The greater quenching of emission upon addition of $\mathrm{Cu}^{2+}$ to the solutions of both 1 and $\mathbf{2}$ containing other metal ions (Figure 7) corroborates the selectivity in the binding process.

The relative change in emission intensity of 1 at $413 \mathrm{~nm}$ was used to determine the binding constants [37]. The measured emission $\left(I_{0} / \Delta I\right)$ at $413 \mathrm{~nm}$ when plotted against the inverse of the concentration of guest solution fits almost a linear relationship. The ratio of the intercept versus slope gives the association constants (Table 1). A similar method for determining the binding constants with 2 was employed. As can be seen from Table 1, the receptor $\mathbf{1}$ has a marked selectivity for $\mathrm{Cu}^{2+}$ over
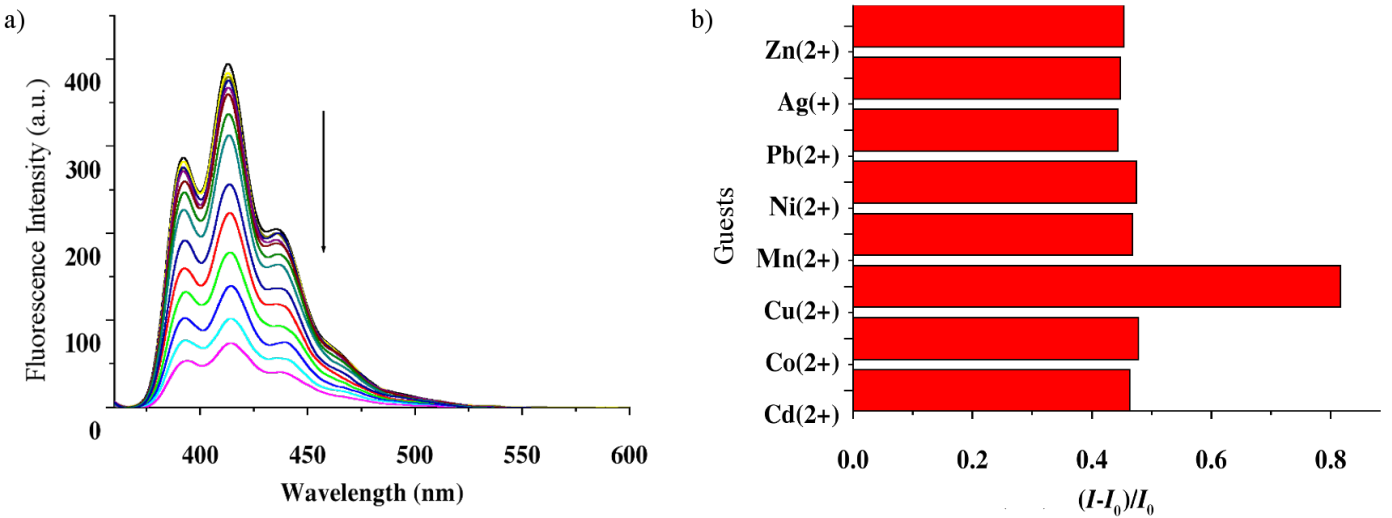

Figure 5: a) Emission spectra of receptor $2\left(c=1.48 \times 10^{-5} \mathrm{M}\right)$ during titration with $\mathrm{Cu}^{2+}$ ion $\left(c=4.4 \times 10^{-4} \mathrm{M}\right)$ in $\mathrm{CH}_{3} \mathrm{CN}$ containing $0.02 \% \mathrm{DMSO}$ $\left(\lambda_{\mathrm{ex}}=348 \mathrm{~nm}\right)$; b) fluorescence ratio $\left(I-I_{0} / I_{0}\right)$ of receptor $2\left(c=1.48 \times 10^{-5} \mathrm{M}\right)$ at $413 \mathrm{~nm}$ upon addition of 20 equiv of a particular guest in $\mathrm{CH}_{3} \mathrm{CN}$ containing $0.02 \%$ DMSO $\left(\lambda_{\mathrm{ex}}=348 \mathrm{~nm}\right)$. 

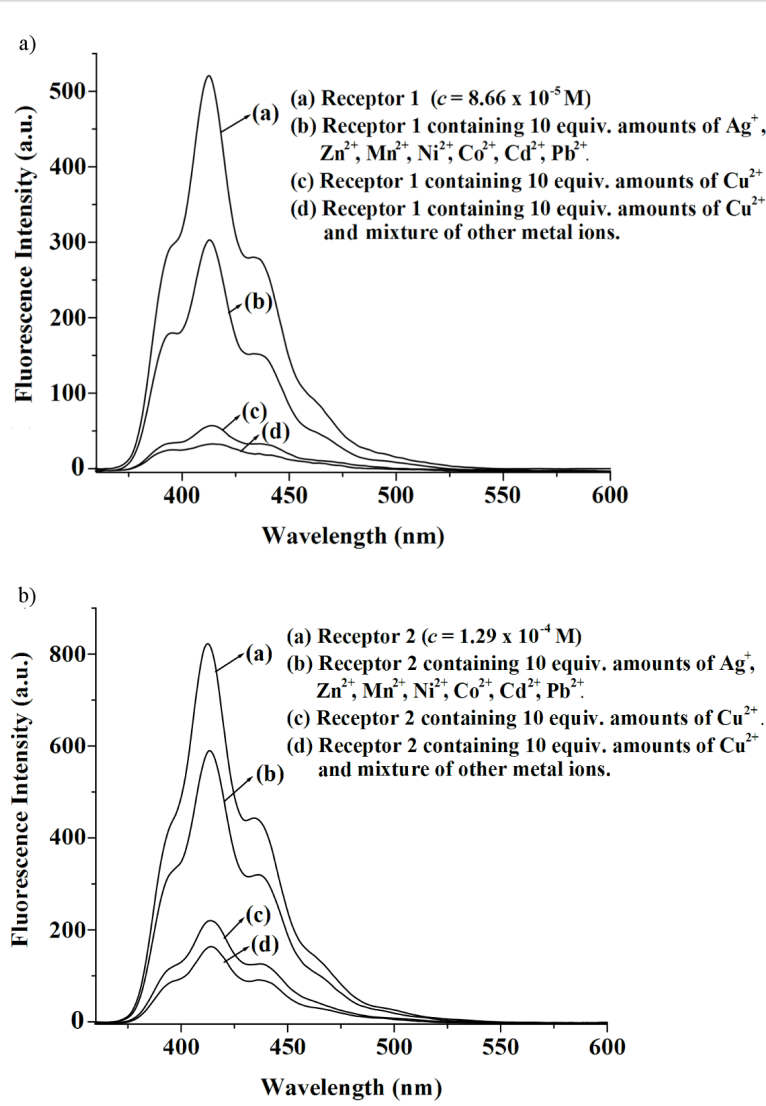

Figure 7: Change in emission of $1\left(c=8.66 \times 10^{-5} \mathrm{M}\right)(\mathrm{a})$ and $2(c=$ $\left.1.29 \times 10^{-4} \mathrm{M}\right)(\mathrm{b})$ upon addition of 10 equiv amounts of $\mathrm{Cu}^{2+}$ in the presence and absence of other metal ions in $\mathrm{CH}_{3} \mathrm{CN}$ containing $0.2 \%$ DMSO.

other metal ions. A similar feature is noted for $\mathbf{2}$ but the efficiency in selectivity is found to be less when compared to $\mathbf{1}$. This is due to the more basic character of the amino group as
Table 1: Association constants $\left(K_{\mathrm{a}}\right.$ in $\left.\mathrm{M}^{-1}\right)$ for 1 and 2 with the metal ions by fluorescence method.

\begin{tabular}{lll} 
Guests $^{\mathrm{a}}$ & $K_{\mathrm{a}}^{\mathrm{b}, \mathrm{d}}$ for $\mathbf{1}$ & $K_{\mathrm{a}}^{\mathrm{c}, \mathrm{d}}$ for 2 \\
\hline $\mathrm{Cu}^{2+}$ & $5.33 \times 10^{4}$ & $8.88 \times 10^{3}$ \\
$\mathrm{Ag}^{+}$ & $2.17 \times 10^{2}$ & $1.40 \times 10^{3}$ \\
$\mathrm{Co}^{2+}$ & $8.80 \times 10^{2}$ & $5.16 \times 10^{3}$ \\
$\mathrm{Cd}^{2+}$ & $2.21 \times 10^{3}$ & $5.72 \times 10^{3}$ \\
$\mathrm{~Pb}^{2+}$ & $1.89 \times 10^{3}$ & $5.78 \times 10^{3}$ \\
$\mathrm{Mn}^{2+}$ & $9.10 \times 10^{2}$ & $5.09 \times 10^{3}$ \\
$\mathrm{Ni}^{2+}$ & $2.01 \times 10^{3}$ & $3.41 \times 10^{3}$ \\
$\mathrm{Zn}^{2+}$ & $3.37 \times 10^{3}$ & $1.19 \times 10^{3}$ \\
\hline
\end{tabular}

aperchlorate salts were used;

bDetermined at $413 \mathrm{~nm}$;

'Determined at $413 \mathrm{~nm}$;

dErrors in $K_{\mathrm{a}}$ were $\leq 5 \%$.

well as the ring nitrogen at WC site in $\mathbf{1}$ in the presence of the anthracenyl group on the amine functionality. The binding constant curves are given in Figure 8 and the linear nature of the curves establishes 1:1 binding model during the interaction process.

The ground state interaction properties of $\mathbf{1}$ and $\mathbf{2}$ were also investigated with the same metal ions in $\mathrm{CH}_{3} \mathrm{CN}$ containing $0.1 \%$ DMSO. The concomitant changes in absorption spectra of $\mathbf{1}$ and $\mathbf{2}$ were, however, only minor for all metal ions examined with the exception of $\mathrm{Cu}^{2+}$. Figure 9a shows the changes in the absorption spectra of $\mathbf{1}$ upon titration with $\mathrm{Cu}^{2+}$ ions. The greater change in absorption of $\mathbf{1}$ at 268 and $325 \mathrm{~nm}$ produced an isosbestic point, indicating the presence of a unique complex in equilibrium with the neutral receptor. The progressive decrease in absorbance at $366 \mathrm{~nm}$ for anthracene moiety further
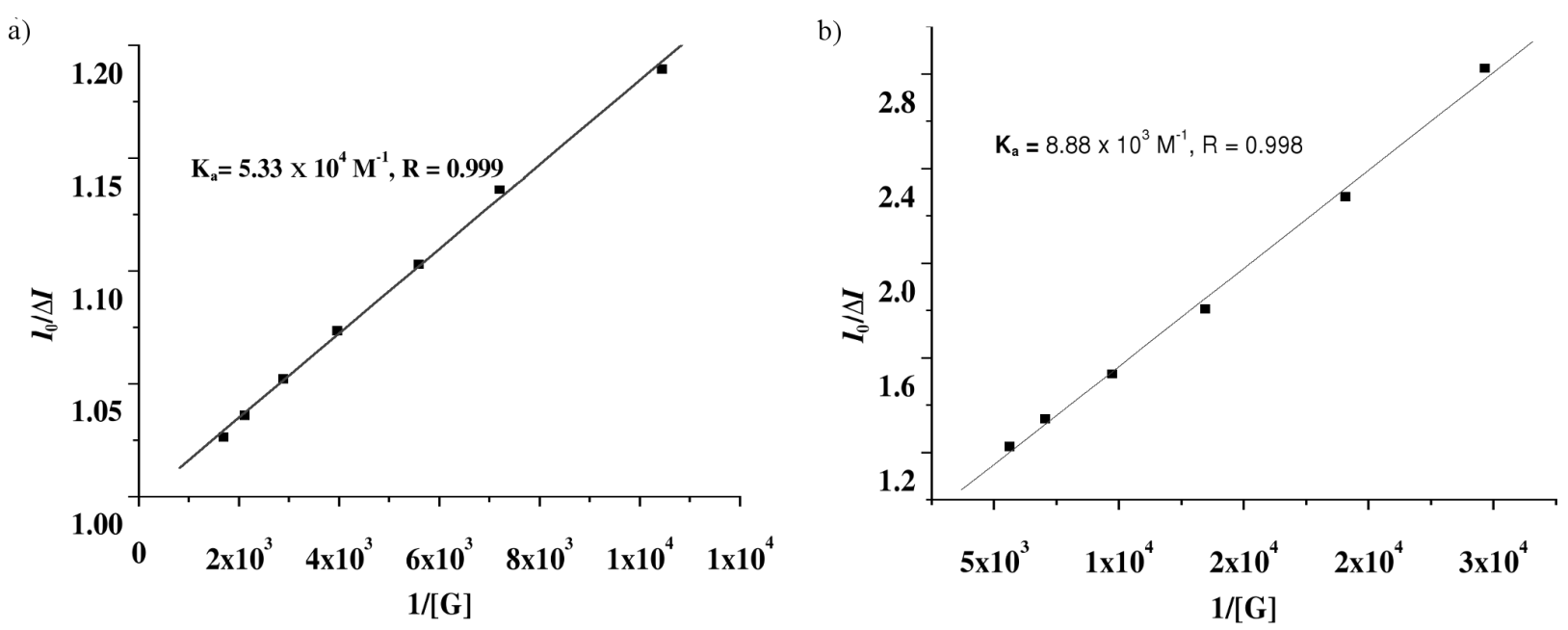

Figure 8: a) Binding constant curve for 1 with $\mathrm{Cu}^{2+}$ ion; b) binding constant curve for 2 with $\mathrm{Cu}^{2+}$ ion. 

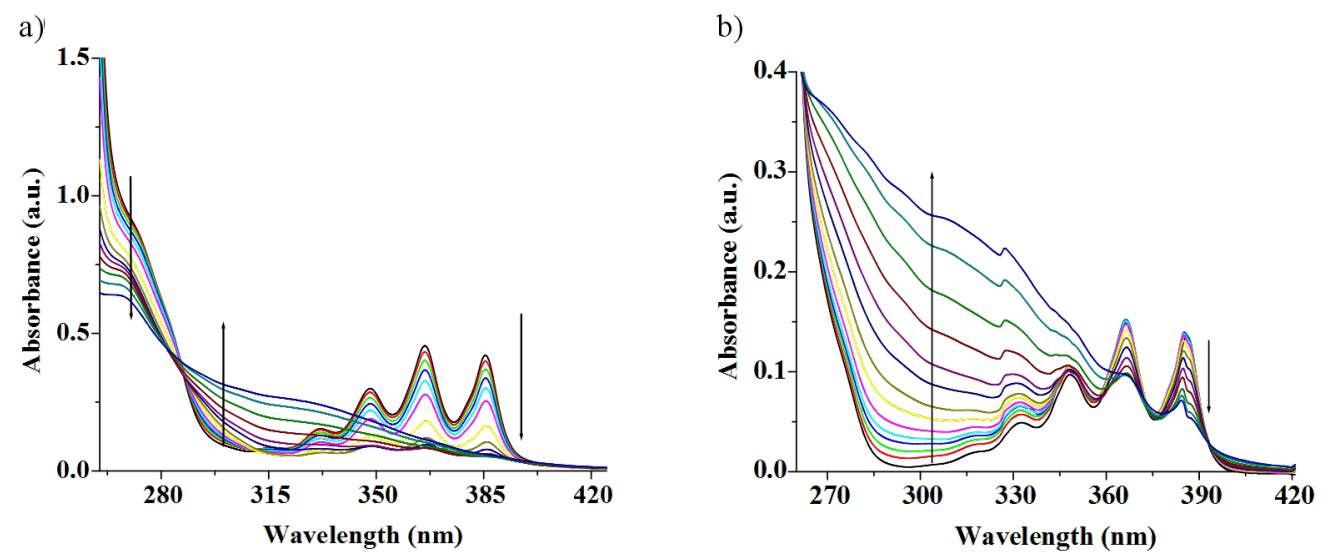

Figure 9: a) Absorption spectra of receptor $1\left(c=5.09 \times 10^{-5} \mathrm{M}\right)$ upon gradual addition of $\mathrm{Cu}^{2+}$ ion $\left(c=1.4 \times 10^{-3} \mathrm{M}\right)$ in $\mathrm{CH}_{3} \mathrm{CN}_{\mathrm{containing}} 0.02 \%$ DMSO; b) absorption spectra of receptor $2\left(c=1.48 \times 10^{-5} \mathrm{M}\right)$ upon gradual addition of $\mathrm{Cu}^{2+}$ ion $\left(c=4.4 \times 10^{-4} \mathrm{M}\right)$ in $\mathrm{CH}_{3} \mathrm{CN}_{\mathrm{containing}} 0.1 \%$ DMSO.

suggests the strong participation of anthracene in a $\pi$-cation complexation event. Similarly, receptor $2\left(c=1.48 \times 10^{-5} \mathrm{M}\right)$ showed intense absorption bands, characteristic of the anthracene moiety at 348,365 and $385 \mathrm{~nm}$ in $\mathrm{CH}_{3} \mathrm{CN}$ containing $0.1 \%$ DMSO. Upon adding metal ions as their perchlorate salts the absorption intensity decreased to the different extents. In case of $\mathrm{Cu}^{2+}$, the absorption changed significantly in the region at $314 \mathrm{~nm}$ and was accompanied by an isosbestic point at 372 $\mathrm{nm}$, which indicates the formation of a supramolecular complex between 2 with $\mathrm{Cu}^{2+}$ ion. Figure $9 \mathrm{~b}$ displays the change in absorption of 2 with addition of $\mathrm{Cu}^{2+}$ ions in $\mathrm{CH}_{3} \mathrm{CN}$ containing $0.1 \%$ DMSO. It is of note that the change in absorbance of the peaks for anthracene moiety is small compared to that in the case of $\mathbf{1}$ with $\mathrm{Cu}^{2+}$ thereby suggesting a relatively weak cation- $\pi$ interaction with the anthracenyl function, situated at the distal position from the interacting region. Such findings in the ground state were not observed in case of other cations even with $\mathrm{Ag}^{+}$(Figure 10a for receptor 2). This was also found for 1 with $\mathrm{Ag}^{+}$ions (Figure 10b). The resulting isotherm fits nicely a 1:1 binding model (Supporting Information File 1).

However, the cation- $\pi$ interaction in both $\mathbf{1}$ and $\mathbf{2}$ is due solely to the presence of adenine moiety which is involved in the binding of metal ions. This was proved by carrying out the UV-vis titration experiment using anthracene only. Figure 11 shows the decrease in absorbance of anthracene upon gradual addition of $\mathrm{Cu}^{2+}$ ions. It is of note that the decrease in absorbance of anthracene is much less compared to the cases of $\mathbf{1}$ and a)

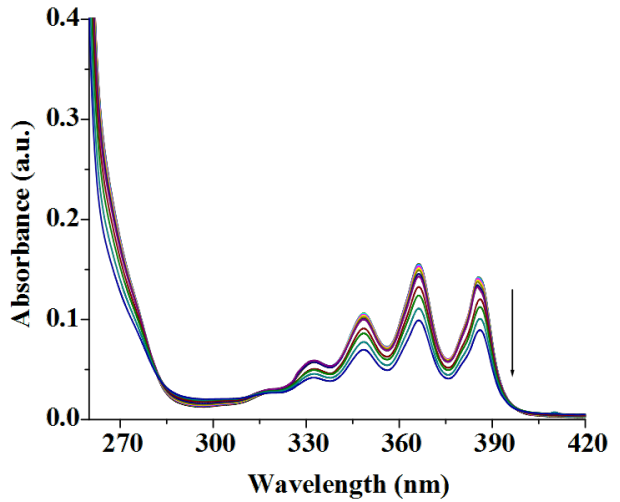

b)

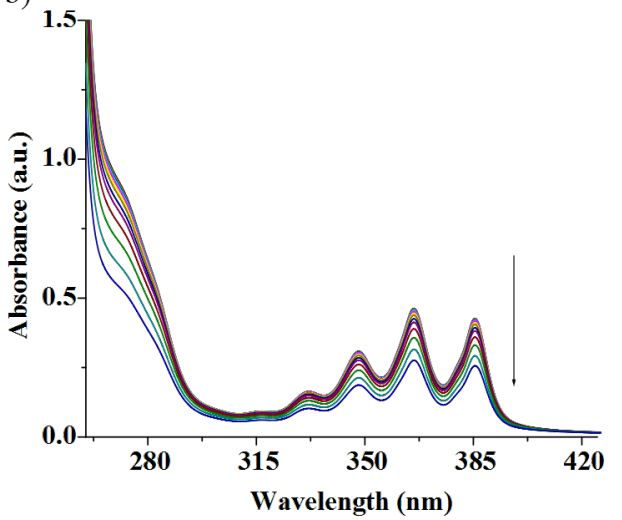

Figure 10: a) Absorption spectra of receptor $2\left(c=1.48 \times 10^{-5} \mathrm{M}\right)$ upon gradual addition of $\mathrm{Ag}^{+}$ion $\left(c=4.4 \times 10^{-4} \mathrm{M}\right)$ in $\mathrm{CH}_{3} \mathrm{CN}$ containing $0.1 \%$ DMSO; b) absorption spectra of receptor $1\left(c=5.09 \times 10^{-5} \mathrm{M}\right)$ upon gradual addition of $\mathrm{Ag}^{+}$ion $\left(c=1.4 \times 10^{-3} \mathrm{M}\right)$ in $\mathrm{CH}_{3} \mathrm{CN}$ containing $0.02 \%$ DMSO. 
2 with $\mathrm{Cu}^{2+}$. During the interaction process no other changes were observed. This finding thus indicates that the adenine moiety in both $\mathbf{1}$ and $\mathbf{2}$ acts as a metal ion binding site for which participation of anthracene in cation- $\pi$ interaction is facilitated upon binding of metal ions, especially $\mathrm{Cu}^{2+}$ ion.

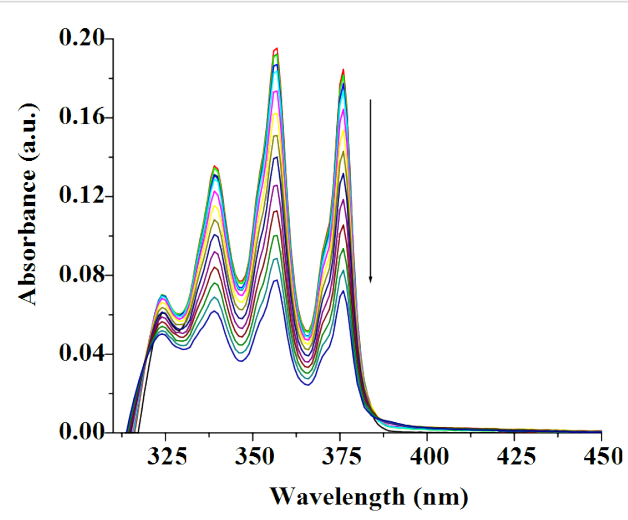

Figure 11: Absorption spectra of anthracene $\left(c=2.39 \times 10^{-5} \mathrm{M}\right)$ upon gradual addition of $\mathrm{Cu}^{2+}$ ion $\left(c=1.20 \times 10^{-3} \mathrm{M}\right)$ in $\mathrm{CH}_{3} \mathrm{CN}$ containing $0.1 \%$ DMSO.

\section{Conclusion}

In conclusion, the above studies have led to the development of adenine-linked fluorescent probes $\mathbf{1}$ and $\mathbf{2}$, which selectively respond to copper ions. The chemosensors display fluorescent changes upon complexation with $\mathrm{Cu}^{2+}$ ions. The emission of $\mathbf{1}$ is greatly decreased in the presence of $\mathrm{Cu}^{2+}$ compared to $\mathbf{2}$ and thus underlines the fact that the sensing ability for metal ions of adenine motif is appreciable and effective when the fluorescent probe resides in close proximity to the $\mathrm{WC} / \mathrm{HG}$ site. We believe that these observations regarding the interaction between the adenine moiety and $\mathrm{Cu}^{2+}$ ions should serve as the basis for new strategies to design new chemosensors based on adenine even although copper ion recognition by other systems has been described. Further progress along this direction is underway in our laboratory.

\section{Supporting Information}

\section{Supporting Information File 1}

Stoichiometry curves for $\mathbf{1}$ and $\mathbf{2}$ with $\mathrm{Cu}^{2+}$ ions.

[http://www.beilstein-journals.org/bjoc/content/

supplementary/1860-5397-6-44-S1.pdf]

\section{Acknowledgements}

We thank CSIR, Government of India for financial support. TS thanks CSIR, Government of India for providing fellowship. We also thank DST, Government of India for providing facilities in the department under FIST program.

\section{References}

1. de Silva, A. P.; Gunaratne, H. Q. N.; Gunnalaugsson, T. A.; Huxley, T. M.; McCoy, C. P.; Rademacher, J. T.; Rice, T. E. Chem. Rev. 1997, 97, 1515. doi:10.1021/cr960386p

2. Lai, C.-Y.; Trewyn, B. G.; Jeftinija, D. M.; Jeftinija, K.; Xu, S.; Jeftinija, S.; Lin, V. S.-Y. J. Am. Chem. Soc. 2003, 125, 4451. doi:10.1021/ja028650I

3. Czarnik, A. W. Acc. Chem. Res. 1994, 27, 302. doi:10.1021/ar00046a003

4. Quang, D. T.; Kim, J. S. Chem. Rev. 2007, 107, 3780. doi:10.1021/cr068046j

5. Muthaup, G.; Schlicksupp, A.; Hess, L.; Beher, D.; Ruppert, T.; Masters, C. L.; Beyreuther, K. Science 1996, 271, 1406. doi:10.1126/science.271.5254.1406

6. Løvstad, R. A. BioMetals 2004, 17, 111. doi:10.1023/B:BIOM.0000018362.37471.0b

7. Barceloux, D. G.; Barceloux, D. J. Clin. Toxicol. 1999, 37, 217. doi:10.1081/CLT-100102421

8. Sarkar, B. In Metal ions in biological systems; Siegel, H.; Siegel, A., Eds.; Marcel Dekker: New York, 1981; Vol. 12, pp 233 ff.

9. Que, E. L.; Domaille, D. W.; Chang, C. J. Chem. Rev. 2008, 108, 1517. doi:10.1021/cr078203u

10. Jung, H. S.; Park, M.; Han, D. Y.; Kim, E.; Lee, C.; Ham, S.; Kim, J. S. Org. Lett. 2009, 11, 3378. doi:10.1021/ol901221q

11. Nisar Ahamed, B.; Ravikumar, I.; Ghosh, P. New J. Chem. 2009, 33, 1825. doi:10.1039/b9nj00204a

12. Zheng, Y.; Gattas-Asfura, K. M.; Konka, V.; Leblanc, R. M. Chem. Commun. 2002, 2350. doi:10.1039/b208012e

13. Kim, H. J.; Hong, J.; Hong, A.; Ham, S.; Lee, J. H.; Kim, J. S. Org. Lett. 2008, 10, 1963. doi:10.1021/ol800475d

14. Jung, H. S.; Kwon, P. S.; Lee, J. W.; Kim, J. L.; Hong, C. S.; Kim, J. W.; Yan, S.; Lee, J. Y.; Lee, J. H.; Joo, T.; Kim, J. S. J. Am. Chem. Soc. 2008, 131, 2008. doi:10.1021/ja808611d

15. Weng, Y.-Q.; Yue, F.; Zhong, Y.-R.; Ye, B.-H. Inorg. Chem. 2007, 48, 7749. doi:10.1021/ic061709v

16. Martinez, R.; Zapata, F.; Caballero, A.; Espinosa, A.; Tarraga, A.; Molina, P. Org. Lett. 2006, 8, 3235. doi:10.1021/ol0610791

17. Xiang, Y.; Tong, A.; Jin, P.; Ju, Y. Org. Lett. 2006, 8, 2863. doi:10.1021/ol0610340

18. Zheng, Y.; Gattás-Asfura, K. M.; Konka, V.; Leblance, R. M. Chem. Commun. 2002, 2350. doi:10.1039/b208012e

19. Kim, S. H.; Kim, J. S.; Park, S. M.; Chang, S.-K. Org. Lett. 2006, 8 , 371. doi:10.1021/ol052282j

20. Qi, X.; Jun, E. J.; Xu, L.; Kim, S.-J.; Hong, J. S. J.; Yoon, Y. J.; Yoon, J. J. Org. Chem. 2006, 71, 2881. doi:10.1021/jo052542a

21. Jung, H. S.; Park, M.; Han, D. Y.; Kim, E.; Lee, C.; Ham, S.; Kim, J. S. Org. Lett. 2009, 11, 3378. doi:10.1021/ol901221q

22. Ravikumar, I.; Nisar Ahamed, B. N.; Ghosh, P. Tetrahedron 2007, 63, 12940. doi:10.1016/j.tet.2007.10.041

23. Kumar, S.; Singh, P.; Kaur, S. Tetrahedron 2007, 63, 11724. doi:10.1016/j.tet.2007.08.101

24. Yang, J.-S.; Lin, C.-S.; Hwang, C. Org. Lett. 2001, 3, 889. doi:10.1021/ol015524y

25. Tan, Z.-J.; Chen, S.-J. Biophys. J. 2006, 90, 1175. doi:10.1529/biophysj.105.070904

26. Liu, L.; Zhang, G.; Xiang, J.; Zhang, D.; Zhu, D. Org. Lett. 2008, 10, 4581. doi:10.1021/ol801855s And references cited therein.

27. Mishra, A. K.; Purohit, C. S.; Verma, S. CrystEngComm 2008, 10 , 1296. doi:10.1039/b811205n 
28. Ghosh, K.; Sen, T. Tetrahedron Lett. 2008, 49, 7204. doi:10.1016/j.tetlet.2008.10.009

29. Ghosh, K.; Sen, T.; Fröhlich, R. Tetrahedron Lett. 2007, 48, 7022. doi:10.1016/j.tetlet.2007.07.110

30. Compound 1: $\mathrm{mp}=140-145^{\circ} \mathrm{C},{ }^{1} \mathrm{H}$ NMR $\left(500 \mathrm{MHz}, \mathrm{CDCl}_{3}\right): \delta 8.58(\mathrm{br}$ s, $1 \mathrm{H}), 8.47(\mathrm{~s}, 1 \mathrm{H}), 8.37(\mathrm{~d}, 2 \mathrm{H}, J=10 \mathrm{~Hz}), 8.03(\mathrm{~d}, 2 \mathrm{H}, J=10 \mathrm{~Hz})$, 7.54-7.44 (m, 4H), 7.39 (br s, 1H), 6.15 (br s, -NH-, 1H), 5.78 (br s, $2 \mathrm{H}), 4.10(\mathrm{t}, 2 \mathrm{H}, J=5 \mathrm{~Hz}), 1.85-1.79(\mathrm{~m}, 2 \mathrm{H}), 1.37-1.30(\mathrm{~m}, 2 \mathrm{H}), 0.94$ $(\mathrm{t}, 3 \mathrm{H}, J=5 \mathrm{~Hz}) \cdot{ }^{13} \mathrm{C}$ NMR $\left(125 \mathrm{MHz}, \mathrm{CDCl}_{3}\right): \delta 149.0,148.1,134.4$, 126.4, 125.5, 124, 123.6, 122.9, 121.4, 120.2, 119.0, 114.5, 65.6, 38.5, $27.0,14.8,8.5$ (one carbon in the aromatic region was not found due to overlapping.). FTIR: $v \mathrm{~cm}^{-1}(\mathrm{KBr})$ : 3416, 3050, 2853, 2954, 2924, 1611, 1577, 1470, 1323; Mass (EI): $382.4(\mathrm{M}+\mathrm{H})^{+}, 269.9,248.3$, 192.4. Compound 2: $\mathrm{mp}=240{ }^{\circ} \mathrm{C},{ }^{1} \mathrm{H}$ NMR $\left(500 \mathrm{MHz}, d_{6}\right.$-DMSO): $\delta$ $8.75(\mathrm{~s}, 1 \mathrm{H}), 8.59$ (d, 2H, J = $8 \mathrm{~Hz}), 8.34(\mathrm{~s}, 1 \mathrm{H}), 8.17(\mathrm{~d}, 2 \mathrm{H}, J=8 \mathrm{~Hz})$, $7.62(\mathrm{t}, 2 \mathrm{H}, J=8 \mathrm{~Hz}), 7.57$ (t, $2 \mathrm{H}, J=8 \mathrm{~Hz}), 7.47$ (s, 1H), $7.26(\mathrm{~s}, 2 \mathrm{H})$, 6.34 (s, 2H). FTIR: $v \mathrm{~cm}^{-1}(\mathrm{KBr}): 3356,2923,2852,1746,1649,1597$, 1384, 1038. Anal. Calcd for $\mathrm{C}_{20} \mathrm{H}_{15} \mathrm{~N}_{5}$ : C, 73.83; $\mathrm{H}, 4.65 ; \mathrm{N}, 21.52$. Found: C, 73.55; H, 4.62; N, 20.98.

31. AM1 calculation was performed using minimal valence basis as STO $3 G$ in Argus Lab 4.0.1, copyright (c) 1972-2004 Mark Thompson and Planaria Software LLC. http://www.arguslab.com.

32. Engel, J. D.; Von Hippel, P. H. Biochemistry 1974, 13, 4143. doi:10.1021/bi00717a013

33. Plante, J. P.; Glass, T. E. Org. Lett. 2006, 8, 2163 doi:10.1021/ol060641k

34. Choi, M.-Y.; Chan, M. C.-W.; Zhang, S.; Cheung, K.-K.; Che, C.-M.; Wong, K.-Y. Organometallics 1999, 18, 2074. doi:10.1021/om990009d

35. Villata, L. S.; Wolcan, E.; Feliz, M. R.; Capparelli, A. L. J. Phys. Chem. A 1999, 103, 5661. doi:10.1021/jp983714t

36. Kaur, S.; Kumar, S. Tetrahedron Lett. 2004, 45, 5081. doi:10.1016/j.tetlet.2004.04.185

37. Chou, P. T.; Wu, G. R.; Wei, C. Y.; Cheng, C. C.; Chang, C. P.; Hung, F. T. J. Phys. Chem. B. 2000, 104, 7818.

\section{License and Terms}

This is an Open Access article under the terms of the Creative Commons Attribution License (http://creativecommons.org/licenses/by/2.0), which permits unrestricted use, distribution, and reproduction in any medium, provided the original work is properly cited.

The license is subject to the Beilstein Journal of Organic Chemistry terms and conditions:

(http://www.beilstein-journals.org/bjoc)

The definitive version of this article is the electronic one which can be found at: $\underline{\text { doi:10.3762/bjoc. } 6.44}$ 